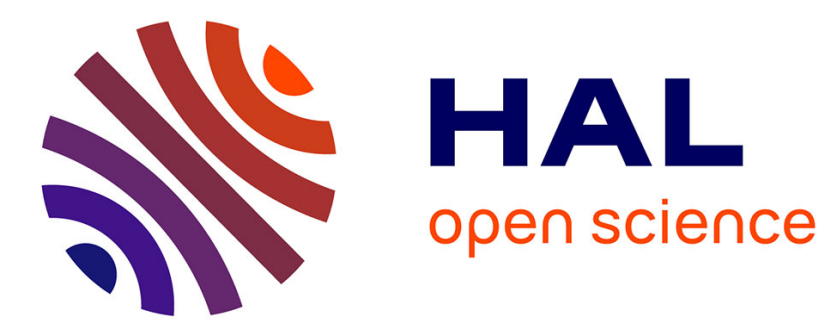

\title{
SIPPOM-WOSR: A Simulator for Integrated Pathogen POpulation Management of phoma stem canker on Winter OilSeed Rape: I. Description of the model
}

Elise Pelzer, Lydia Bousset, Marie-Helene Jeuffroy, M.U. Salam, X. Pinochet, M. Boillot, Jean-Noel Aubertot

\section{To cite this version:}

Elise Pelzer, Lydia Bousset, Marie-Helene Jeuffroy, M.U. Salam, X. Pinochet, et al.. SIPPOMWOSR: A Simulator for Integrated Pathogen POpulation Management of phoma stem canker on Winter OilSeed Rape: I. Description of the model. Field Crops Research, 2010, 118 (1), pp.73-81. 10.1016/j.fcr.2010.04.007 . hal-01173218

\author{
HAL Id: hal-01173218 \\ https://hal.science/hal-01173218
}

Submitted on 30 May 2020

HAL is a multi-disciplinary open access archive for the deposit and dissemination of scientific research documents, whether they are published or not. The documents may come from teaching and research institutions in France or abroad, or from public or private research centers.
L'archive ouverte pluridisciplinaire HAL, est destinée au dépôt et à la diffusion de documents scientifiques de niveau recherche, publiés ou non, émanant des établissements d'enseignement et de recherche français ou étrangers, des laboratoires publics ou privés. 


\title{
SIPPOM-WOSR: A Simulator for Integrated Pathogen POpulation Management of phoma stem canker on Winter OilSeed Rape I. Description of the model
}

\author{
E. Lô-Pelzer ${ }^{\mathrm{a}}$, L. Bousset ${ }^{\mathrm{b}}$, M.H. Jeuffroy ${ }^{\mathrm{a}}$, M.U. Salam ${ }^{\mathrm{c}}$, X. Pinochet ${ }^{\mathrm{e}}$, M. Boillot $^{\mathrm{e}}$, J.N. Aubertot $^{\mathrm{d}}$
}

${ }^{\text {a }}$ INRA, UMR211 Agronomie, BP01, F-78850 Thiverval-Grignon, France

b INRA, Agrocampus Rennes, UMR1099 BiO3P (Biology of Organisms and Populations applied to Plant Protection), F-35653 Le Rheu, France

${ }^{c}$ Centre for Cropping Systems, Department of Agriculture and Food, Western Australia, PO Box 483, Northam, WA 6401, Australia

${ }^{\mathrm{d}}$ INRA, UMR 1248 AGIR, BP 52627 Auzeville, F-31326 Castanet Tolosan, France

${ }^{\mathrm{e}}$ Cetiom BP04, F-78850, Thiverval-Grignon, France

\begin{abstract}
To durably control phoma stem canker (Leptosphaeria maculans/Leptosphaeria biglobosa) in oilseed rape by preserving the efficacy of specific resistances, the design of cropping systems is required, combining different aspects of crop management over time and at the regional scale. Modelling is a practical means to do so. To this end, the structure of SIPPOM, a Simulator for Integrated Pathogen POpulation Management, is presented. By linking epidemiological, population and crop model approaches, it simulates both the quantitative evolution (size) and qualitative evolution (genetic structure) of $L$. maculans population under the influence of various cropping systems. It involves five sub-models: (i) primary inoculum production; (ii) ascospore dispersal; (iii) crop development; (iv) plant infection, disease severity, and yield loss; and (v) changes in the genetic structure of pathogen populations over time. The input variables are weather data, soil characteristics, the description of cropping systems (crop sequence and winter oilseed rape crop management, including cultivars, sowing, fungicide, and tillage) and their spatial distribution (the model is spatially explicit), plus the initial size and genetic structure of pathogen populations. The genetic evolutionary forces taken into account are migration, selection, and recombination. The model simulates disease severity and the genetic structure of the pathogen population, in addition to the attainable yield less yield loss caused by the disease. The economic and environmental performances of the simulated strategies are computed using technical operation costs, crop prices, and yields. The underlying hypotheses are discussed in light of advantages and possible improvements of the model. Possible uses of SIPPOM are proposed with respect to the design of collective strategies for the durable control of phoma stem canker on winter oilseed rape at a regional scale.
\end{abstract}

Keywords: Blackleg, Leptosphaeria maculans, Brassica napus, Model, Resistance durability, Integrated Pest Management

\section{Introduction}

Phoma stem canker (also known as blackleg), caused by the species complex Leptosphaeria maculans/Leptosphaeria biglobosa, has a major economic impact on oilseed rape yield worldwide (Fitt et al., 2006). It is usually controlled genetically through the use of cultivars with specific or quantitative resistances. However, specific resistances remain effective for only a few years (Rouxel et al., 2003). In order to extend the durability of efficacy of specific resistance, it is necessary to reduce the size of pathogen populations and limit the selection pressure exerted on pathogen populations (Integrated Avirulence Management, Aubertot et al., 2006a).

It is known that the size of $L$. maculans/L. biglobosa populations can be reduced using chemical and cultural control methods such as tillage, the choice of sowing date and rate as well as nitrogen management at the cropping system level (Aubertot et al., 2004a). For instance, the quantity of primary inoculum is reduced by deep tillage. The coincidence between ascospore release and the most sensitive stage of oilseed rape can be avoided by shifting the sowing date. The leaf area receiving ascospores (and thus the risk and intensity of infection) is impacted by crop rate and nitrogen supply at sowing. Ascospores are wind-dispersed up to several kilometres away (West et al., 2001, Marcroft et al., 2004), and disease control can also be improved by reducing spore flow between fields. This requires taking into consideration the distance between the fields 
which are the source of ascospores and new Winter OilSeed Rape (WOSR) fields as well as the size of both source and target fields.

Limiting the selection pressure exerted on pathogen populations by specific resistances implies the need to account for the specific resistant gene distribution in space (McDonald and Linde, 2002). In the case of phoma stem canker, the inoculum dispersal exceeding the field scale requires to take into consideration combinations of control methods at the regional scale (and not only at the field scale, Aubertot et al., 2006a). Moreover, in order to test strategies that delay loss of efficacy of specific resistances, and because of polyetical processes in the epidemic cycle of the disease, it is also necessary to take into consideration the evolution of pathogen populations as well as the control of the disease over several years.

The design of cropping systems is required to durably bring phoma stem canker under control. Genetic, chemical, and cultural control methods have to be combined over time and at the regional scale, in light of the economical, ecological, and toxicological requirements of Integrated Crop Management (IOBC-SROP, 1973, Ferron and Deguine, 2005). Due to spatial and time scale and the limiting nature of field testing, modelling is a practical means to simulate the interactions between crop development and growth and the pathogen population evolution under the influence of cultural practices. Population models, studying virulence dynamics in plant pathogen populations (e.g., Kiyosawa, 1982, Shi-Mai, 1991, Leonard, 1993, Hovmøller et al., 1997, Van den Bosch and Gilligan, 2003) and epidemiological models, simulating parts of the epidemic cycle of phoma stem canker (e.g., Aubertot et al., 2004b, Schneider et al., 2006, Salam et al., 2007), need to be embedded within the crop models, taking into account cultural practices along with soil and weather characteristics to simulate oilseed rape growth at the field and annual scales (e.g., Azodyn-rape, Jeuffroy and Recous, 1999, Jeuffroy et al., 2003; CERES, Gabrielle et al., 1998). Moreover, the outputs of the model should not only characterize the pathogen population and the disease severity; they should also characterize crop production and the economic profit for farmers along with the environmental impact of the simulated strategies.

We present here SIPPOM-WOSR, a Simulator for Integrated Pathogen POpulation Management. It is a model that links epidemiological, population and crop model approaches, simulating both the quantitative (size) and qualitative evolution (genetic structure) of the L. maculans population under the influence of various cropping systems. It can be used to design and assess cropping systems that seek to control phoma stem canker while both preserving the efficacy of specific resistance and meeting requirements of Integrated Crop Management (ICM). In the following sections, the structure and the equations of the overall model, along with simulation results to exemplify the use of SIPPOM-WOSR, are presented. The underlying hypotheses are discussed in light of advantages and possible improvements of the model. Possible uses of SIPPOM are proposed with respect to the design of collective strategies for the durable control of phoma stem canker on winter oilseed rape at the regional scale. A companion paper presents the results of a sensitivity analysis that reveals the suitability of SIPPOM-WOSR when it is used to carry out the set objective, that is to say, to rank cropping systems.

\section{Structure of SIPPOM-WOSR}

The basic structure of SIPPOM-WOSR is derived from the spatially explicit prototype described by Aubertot et al. (2006a). SIPPOM is composed of 5 sub-models simulating the primary inoculum production, the ascospore dispersal, changes in the genetic structure of pathogen populations over time, as well as the infection and yield loss in addition to crop-growth dynamics (Fig. 1). The model is adapted to winter oilseed rape, and was parameterised under northern European weather conditions. SIPPOM is a deterministic, spatially explicit model and it has been implemented in Mathematica 5.2 (Wolfram) and Borland C++ builder. 
Figure 1. Flow chart of SIPPOM-WOSR. Sub-models are represented in squares, weather and soil inputs data in diamonds, technical inputs data in ovals, and outputs data in rounded squares. The structure of the pathogen population is an input variable (initial structure), a state variable (simulated each year) as well as an output variable.

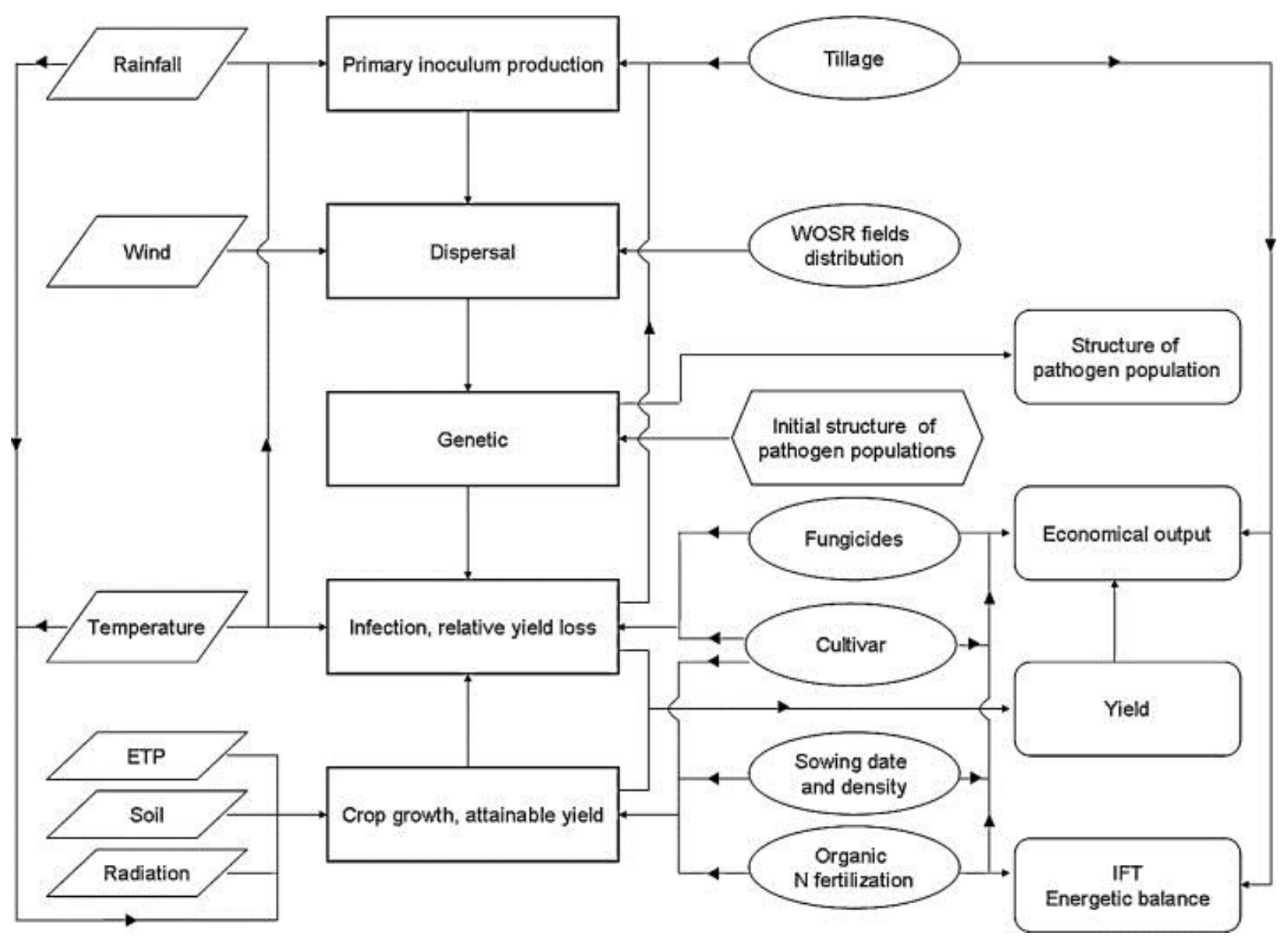

\subsection{Input and output variables of SIPPOM}

The user of SIPPOM determines the number of years to be simulated, the spatial distribution of fields in the landscape, the crop sequence associated with each field, and all the cultivation techniques for oilseed rape including: tillage after harvest (type of tool and date), organic nitrogen application before sowing (type, date, and rate), cultivar, sowing date and rate, as well as chemical treatments (type and date of application) in addition to nitrogen mineral fertilisation in spring (date and rate of application). Specific resistance genes, quantitative resistance level, and potential yield of WOSR cultivars have to be provided by the user, as well as soil characteristics for each field and daily weather data at the regional scale (rainfall, mean temperature, evapotranspiration, radiation, wind speed, and direction). Output variables of the model entail epidemic, agronomic, economical, environmental, and genetic outputs. The epidemical outputs are the $\mathrm{G}_{2}$ Disease Index (characterising canker severity, Aubertot et al., 2004c) and the associated relative yield loss. The agronomic output is the actual yield (attainable yield less the disease). The economic output is a pseudo-gross margin taking into account the cost of strategies decided upon: a cost $\left(€ \mathrm{ha}^{-1}\right)$ has been approximated for each cultural practice. Similarly, the energetic cost of each cultural practice has been set (MJ ha ${ }^{-1}$; ADEME et al., 1999) in order to calculate the overall energetic performance of the tested strategies. For the sake of simplicity, economic and environmental costs of each cultural practice as well as the selling price of the crops are constant over the years of simulation. Another environmental output is the Treatment Frequency Index (TFI, Gravesen, 2003). An important output of the model is the structure (frequency of each pathotype, characterized by a combination of avirulence genes) and size of the pathogen population. All outputs are calculated annually for each field of the given region. 


\subsection{Primary inoculum production sub-model}

Primary inoculum production is simulated daily from harvest to the end of the year for each field source of ascospores (cultivated with WOSR the previous season). The importance of tillage to limit inoculum quantity has been pointed out (Schneider, 2005). The sub-model thus describes the vertical displacement of stubble (bases of plant stem left in field after harvest) in soil given the succession of tillage operations applied, as in Schneider (2005). Whenever a tillage operation occurs, stubble is redistributed among soil layers and is decomposed depending on its position in soil. Because the timing of ascospore release impacts canker severity and yield loss risk, the dynamics of pseudothecial maturation are also simulated, based on the model SimMat (Aubertot et al., 2006b).

Pseudothecial maturation takes place only on stubble that remains on the soil surface. Two hypotheses have been made: the stem bases (stubble) are cylindrical, and only half the surface of the stem releases ascospores (no ascospores are released from the stem surface facing the soil). Thanks to these two hypotheses, the surface of stubble per soil surface unit can be deduced from the mass of stubble on soil surface at time $t$ from the WOSR harvest (expressed in days) as $m_{\text {surface }}(t) / \rho d$, where $\rho$ is the mean density of stubble $\left([\rho]=\mathrm{M} \mathrm{L}^{-3}\right)$, and $d$ is the mean diameter of stubble $\left([d]=\mathrm{L}^{2}\right.$; Schneider, 2005). Stubble cannot be fully covered by pseudothecia. The parameter $\tau_{\max }$ estimates the maximum rate of stubble that can be covered with pseudothecia. The maximum surface of stubble covered with pseudothecia per soil surface unit at time $t$ is therefore $m_{\text {surface }}(t) \tau_{\max } / \rho d$. If $d_{\mathrm{p}}$ is the maximum density of pseudothecia per stubble surface unit covered with pseudothecia $\left(\left[d_{\mathrm{p}}\right]=\mathrm{L}^{-2}\right)$, the maximum potential pseudothecia density per soil surface unit at time $\mathrm{t}$ is $m_{\text {surface }}(t) \tau_{\max } d_{\mathrm{p}} / \rho d$ (Schneider, 2005). Finally, two factors were supposed to reduce the potential pseudothecia density per soil surface unit: the age of the stubble at time $t$ (represented by $\mathrm{e}^{-\beta t}$ in Eq. (1)), and the disease severity at harvest in the field the previous year, as the quantity of pseudothecia produced depends on canker severity (Lô-Pelzer et al., 2009a). The disease index, called the G2 severity disease index (DI) (Aubertot et al., 2004c), is calculated as

$$
\mathrm{DI}=\sum_{i=2}^{6}[2(i-2)+1] n_{i} / \sum_{i=1}^{6}
$$

where $n_{i}$ is the number of plants in the class of severity of canker $i$ ( 6 classes of severity). In SIPPOM, the proportions of plants in each canker severity class ( prop $_{i}$ ) are deduced from the G2 severity disease index (DI) calculated for each field of the previous year (Lô-Pelzer et al., 2009b). The amount of inoculum produced is calculated by multiplying the proportion in each class and the production linked to the canker severity class $i$, represented by the coefficient $a_{i}$ (Lô-Pelzer et al., 2009a). The potential pseudothecia density per soil surface unit $p(t)\left([p(t)]=\mathrm{L}^{-2}\right)$ is therefore calculated each day (time $t$ from the harvest, expressed in days) as:

$$
p(t)=\frac{\left(\sum_{i=1}^{i=6} \text { prop }_{i} \times a_{i}\right) \mathrm{e}^{-\beta t} m_{\text {surface }}(t) \times \tau_{\max } d \mathrm{p}}{\rho d}
$$

with $a_{i}$ is the production of inoculum depending on the canker severity class $i\left(\left[a_{i}\right]=1\right.$, i.e., $a_{i}$ is dimensionless), $\operatorname{prop}_{i}$ is the proportion of plants in canker severity class $i$ ([prop $\left.i\right]=1$ ), $\mathrm{e}^{-\beta t}$ is the relative abundance of pseudothecia depending on time $t$ from the harvest $\left([\beta]=\mathrm{T}^{-1}\right), m_{\text {surface }}(t)$ is the mass of stubble per soil surface unit on time $t$ from the harvest, and taking into account vertical stubble displacement due to tillage $\left(\left[m_{\text {surface }}(t)\right]=\mathrm{M} \mathrm{L}^{-2}\right), \tau_{\max }$ is the parameter estimating the maximum covering rate of pseudothecia per stubble $\left(\left[\tau_{\max }\right]=1\right), d_{\mathrm{p}}$ is the parameter estimating the maximum density of pseudothecia per stubble surface unit covered with pseudothecia $\left(\left[d_{\mathrm{p}}\right]=\mathrm{L}^{-2}\right), \rho$ is the mean density of stubble $\left([\rho]=\mathrm{M} \mathrm{L}^{-3}\right)$, and $d$ is the mean diameter of stubble $([d]=\mathrm{L})$. The parameters $a_{i}$ were estimated using results from an experiment establishing the relationship between canker severity and the quantity of inoculum produced (Lô-Pelzer et al., 2009a). The parameters prop $_{i}$ were estimated using data from CETIOM, the French technical centre for research and development of oilseed production (Lô-Pelzer et al., 2009b). Parameters $\tau_{\max }, d_{\mathrm{p}}, \beta, \rho$, and d were estimated by Schneider (2005). Data provided by the experiment carried out by Lô-Pelzer et al. (2009a) confirmed these values.

The dynamics of pseudothecial maturation are calculated according to the cumulative number of days from harvest that favour, i.e. enable maturation (Salam et al., 2003, Salam et al., 2007). A day favours maturation if the average temperature is between a minimum and maximum temperature, and if the cumulative 
rainfall days before the given day is above a minimum threshold. The probability that a pseudothecium is mature after $\mathrm{N}$ favourable days is supposed to follow the Gaussian law (Aubertot et al., 2006b). Parameterisation of the pseudothecial maturation sub-model was based on initial values published in Salam et al. (2003), followed by a re-parameterisation using French data (Aubertot et al., 2006b). The number of mature pseudothecia per soil surface unit $n_{\mathrm{p}}(t)$ is calculated each day using Eq. (1) and the Gaussian law.

Ascospores are released as soon as it rains. The proportion of released ascospores depends on the rainfall of a given day and on the number of released ascospores the previous days. The number of released ascospores per day $\left(\Delta t=1\right.$ day) and per soil surface unit $\left(\left[n_{\mathrm{a}}\right]=\mathrm{L}^{-2} \mathrm{~T}^{-1}\right)$ is therefore:

$$
n_{\mathrm{a}}(t)=\varepsilon_{n}(t) \frac{\left(n_{\mathrm{p}}(t) d_{\mathrm{a}}-\sum_{i=\text { harvest }}^{t-1} n_{\mathrm{a}}(i)\right)\left(1-\exp \left(-C_{\text {vid }} R(t)\right)\right)}{\Delta t}
$$

with $n_{\mathrm{p}}(t) d_{\mathrm{a}}$ is the number of mature ascospores per soil surface unit on day $t, \sum_{i=\text { harvest }}^{t-1} n_{a}(i)$ is the number of ascospores that have been released until day $t-1, R(t)$ is the cumulative rainfall during day $t([R]=\mathrm{L})$, $\varepsilon_{n}(t)=1$ if $R(t)>0 \mathrm{~mm}$, else $\varepsilon_{n}(t)=0\left(\left[\varepsilon_{n}(t)\right]=1\right), d_{\mathrm{a}}$ is the number of ascospores per pseudothecium $\left(\left[d_{\mathrm{a}}\right]=1\right)$, $C_{v i d}$ is the ascospore release coefficient $\left(\left[C_{v i d}\right]=\mathrm{L}^{-1}\right)$. In Eq. (2), the estimation of $d_{\mathrm{a}}$ is described in Lô-Pelzer et al. (2009a). In order to provide an initial value for the parameter $C_{v i d}$, it was supposed that $99 \%$ of mature pseudothecia release their ascospores after a rainfall event of $100 \mathrm{~mm}$ or more. The combination of parameters to be adjusted was identified by cross-validation, and the values leading to the smallest root mean square error of prediction (Root Mean Square Error of Prediction, RMSEP, Wallach et al., 2006) were selected.

Concerning the evaluation of this sub-model, the simulation of stubble displacement was evaluated by Schneider (2005) using two contrasting successions of tillage operations. The simulated and observed distributions of stubble in the 4 soil layers were fairly similar. A cross-validation of the pseudothecial maturation sub-model was performed over 116 site-years not accounting for all potential year or site correlations. The quality of prediction of mature pseudothecia was judged suitable (Efficiency $=0.51$; RMSEP $=0.22$, Bias $=0.026$ ).

\subsection{Dispersal sub-model}

SIPPOM is spatially explicit. The represented region is rasterized in $50 \mathrm{~m} \times 50 \mathrm{~m}$ pixels, chosen to both obtain reasonable computation times and maintain an acceptable level of detail in the description of the landscape. Each pixel is attributed to a field (or, more generally to a homogenous area). At the beginning of each cultural season, source fields (fields cultivated with oilseed rape the previous season) and target fields (fields cultivated with oilseed rape the given season) are tagged. The stochastic dispersal model presented by Diggle et al. (2002) was rendered deterministic for two main reasons: the analysis of the deviation around the expected values that could be obtained with the stochastic version was deemed unnecessary for the purpose of SIPPOM, and it would have been intractable in terms of computation times. The spore dispersal is calculated daily for each source-target pixel couple, from the earliest emergence of WOSR to the end of the year. All spores are supposed to be released from the centre of the source pixel. The probability for a target pixel to be reached depends on the average daily wind direction which determines the intersection with the target pixel, and on the average daily wind intensity (or wind speed). The dispersal function follows a half-Cauchy-Lorentz density probability function (Diggle et al., 2002). If $l_{i}$ and $l_{f}$ are designated as the distances between the centre of the source pixel and the intersections with the target pixel borders $\left(\left[l_{i}\right]=\left[l_{f}\right]=\mathrm{L}\right)$, the probability that a spore lands in the target pixel at a distance $l_{s}\left(\left[l_{s}\right]=\mathrm{L}\right)$ is therefore:

$$
p\left(l_{i} \leq l_{s} \leq l_{f}\right)=\int_{l_{i}}^{l_{f}} \frac{2 d l}{\pi \gamma\left(1+\left(l^{2} / \gamma^{2}\right)\right)}
$$

This probability therefore depends on the scale parameter $\gamma$ which is, according to Diggle et al. (2002), directly proportional to the averaged daily wind intensity: $\gamma=\mu_{\text {cauchy }} \times$ wind speed, $\mu_{\text {cauchy }}$ characterising this proportionality $\left([\gamma]=\mathrm{L} ;\left[\mu_{\text {cauchy }}\right]=\mathrm{T}\right.$; [ wind speed $\left.]=\mathrm{L} \mathrm{T}^{-1}\right)$. The estimation of the parameter $\mu_{\text {cauchy }}$ has been carried out for the spores of L. maculans under Australian conditions (Salam et al., 2001). 
The stochastic version of the dispersal sub-model was assessed under two contrasting rainfall situations and for 5 infection levels. It showed similar patterns of dispersal between simulations and observations of Colletotrichum gloeosporioides spores (Diggle et al., 2002). The evaluation of the dispersal sub-model in its deterministic version has not been carried out since it provides the exact expected values of the dispersal function that would be obtained with an infinite number of draws. The sharp decrease in the quantity of ascospores deposited within the first few hundred meters, simulated with this sub-model, is in accordance with results presented by Guo and Fernando (2005).

\subsection{Dynamic crop-growth sub-model}

Because yield losses depend on the timing of the infection, it is necessary to precisely simulate crop growth during primary infections under the effects of weather, soil conditions, and cultural practices. The dynamic crop-growth sub-model therefore simulates, daily, from emergence to the end of winter season, and for each target field, the growth stage of the crop when the ascospores are deposited. It also calculates the attainable yield (i.e., the yield only limited by the cultivar potential and the physical and chemical environment of the crop). Azodyn-rape (Jeuffroy et al., 2003) was embedded within SIPPOM-WOSR to simulate the leaf area index and the number of leaves characterising the foliar surface intercepting ascospores during the infection period (used in the infection sub-model) as well as the biomass at the beginning and the end of winter (used for the calculation of the disease index and the attainable yield).

The attainable yield (seed mass per surface unit, [YieldAtt $]=\mathrm{M} \mathrm{L}^{-2}$ ) is calculated from the potential yield of the cultivar ([YieldPot cultivar $]=\mathrm{M} \mathrm{L}^{-2}$ ). A relative yield loss due to water stress during spring is calculated from the hydric deficit HD and maximum water storage HS of the soil (see Appendix 1 in online supplementary file). HD characterises the balance between rain fall and soil and crop transpiration, and it is

calculated between the end of winter and the harvest:

$$
H D=\sum_{d}(E T P d-R d), \text { with ETPd }
$$

, with ETPd is the

daily evapotranspiration of the plant-soil system, $[E T P d]=\mathrm{L}$ and $R d$ is the daily rainfall, $[R d]=\mathrm{L}$. A relative yield loss due to limited plant growth (biomass at the end of winter, BMEW) is also calculated (see Appendix 1 in online supplementary file), as proposed in the "simple-balance" described by Makowski et al. (2005). Mineral nitrogen was considered to be applied optimally in spring and therefore does not affect yield since spring fertilisation has no effect on phoma stem canker development (Söchting and Verreet, 2004). Spring nitrogen fertilisation is only used to calculate the economical output of the tested strategies. The attainable yield is calculated as:

$$
\begin{aligned}
& \text { YieldAtt }=\text { YieldPot }_{\text {cultivar }} \times \text { relativeYieldLosS }_{H S, H D} \times \text { relativeYieldLosS }_{B M E W} \\
& \text { YieldAtt }=\text { YieldPot }_{\text {cultivar }} \times\left(a_{1} H D+a_{2} H S+a_{3} H D \times H S+a_{4}\right) \times b_{0}\left(B M E W / B M E W_{0}\right)^{b_{1}} \exp \left(b_{2} B M E W\right)
\end{aligned}
$$

with $H D$ is the hydric deficit $([H D]=\mathrm{L}), H S$ is the maximum hydric storage in soil $([H S]=\mathrm{L}), B M E W$ is the crop biomass per surface unit at the end of winter, and $B M E W_{0}$ is the crop biomass per surface unit at the end of winter $\left([B M E W]=\left[B M E W_{0}\right]=\mathrm{M} \mathrm{L}^{-2}\right) .\left[a_{1}\right]=\left[a_{2}\right]=\mathrm{L}^{-1},\left[a_{3}\right]=\mathrm{L}^{-2},\left[a_{4}\right]=1,\left[b_{0}\right]=\left[b_{1}\right]=1,\left[b_{2}\right]=\mathrm{M}^{-1} \mathrm{~L}^{2}$. Parameters have been separately estimated to describe the relative yield loss due to water stress and relative yield loss due to plant growth (see Appendix 1 in online supplementary file). Data from East France (provided by E. Hance) have been used to estimate parameters of the relationship simulating yield loss due to water deficit, based on the algorithm proposed by Limaux (1999) for wheat. This relationship has been crossvalidated and had a good predictive quality $\left(\mathrm{RMSEP}=0.22 \mathrm{t} \mathrm{ha}^{-1}\right)$. Data from CETIOM have been used to estimate the parameters of the relationship between yield loss and plant biomass at the end of winter, based on a boundary line relationship (Makowski et al., 2007).

The predictive quality of the crop-growth sub-model during the period of infection was evaluated by the authors of Azodyn-rape (Valantin-Morison et al., 2004). The predictive quality of the relationship establishing the attainable yield (Eq. (4)) has been evaluated with independent data from experiments conducted in France (data provided by M. Morison, see Appendix 1 in online supplementary file). The predictive quality of attainable yield was somewhat poor $\left(\mathrm{RMSEP}=0.80 \mathrm{tha}^{-1}\right)$, with an underestimation (bias $=0.40 \mathrm{t} \mathrm{ha}^{-1}$ ); however, these values fall within the range of values most crop models provide. 


\subsection{Genetic sub-model}

Only evolutionary forces and genetic mechanisms that can be influenced by control strategies are represented in SIPPOM. Selection is influenced by the choice and distribution of specific resistant cultivars. WOSR field distribution impacts migration (simulated in the dispersal sub-model). Recombination is important to consider in the strategies based on the construction of resistant cultivars carrying several resistance genes, as it can lead to accumulation of virulence. Selection, migration, and recombination were represented in SIPPOM. On the other hand, biological data are lacking to estimate parameters that describe mutation and genetic drift that are random phenomenon. Similarly, fitness loss due to the inactivation of the corresponding avirulence gene is not known when a new specific resistant gene is introduced, and, for the time being, it can be neither predicted in fungi nor controlled. All the pathotypes are therefore supposed to have the same capacity of multiplication. In the current version, mutation, genetic drift, and cost of virulence are not represented.

The number of considered avirulence (pathogen) or resistance (cultivar) genes (nvir) is an input variable. All the possible pathotypes (all possible combinations of avirulence genes) are represented by a $2^{\text {nvir }}$ length vector, where each element is coded 1 if the pathotype has the considered avirulence gene, 0 if not. The frequency of each pathotype is initialised in each source pixel and can be calculated as an average over all pixels of a given field. Similarly, cultivars of target pixels are represented by a nvir length vector, coded 1 if the cultivar has the considered resistance gene, 0 if not. The compatibility between source and target pixels is calculated at the beginning of each year of simulation (genetic filter). The compatibility does not exist (and the infection is not possible) if the pathotype has an avirulence gene corresponding to a resistance gene (genefor-gene relationship, Flor, 1971). Ascospores from a source pixel not compatible with the cultivar of the target pixel die. At the end of the dispersal season, new frequencies of pathotypes are calculated for each target pixel considering only effectively infecting ascospores (infection sub-model).

Recombination between pathotypes can be optionally simulated in SIPPOM for 2 or 3 avirulence genes. For two avirulence genes, the physical genetic linkage between genes can be chosen from complete linkage to complete independence. In the second case (recombination with nvir $=3$ ), avirulence genes are considered physically independent. Recombination between higher numbers of avirulence genes would be difficult to represent and to analyse in terms of consequences for outputs, and thus are not taken into consideration here.

\subsection{Infection and relative yield loss sub-model}

The infection sub-model is based on the SimCanker model (Aubertot et al., 2004b). The effect of quantitative resistances that limit canker severity and therefore yield loss has been added to this model. The quantitative resistance is supposed to not alter the number of leaf spots but it hinders the development of canker (Delourme et al., 2006). Thus, the spore infection efficacy only depends on the specific resistance. As little data are available to describe the mechanisms underlying quantitative resistance, its effect is represented in a simplified way: cultivars either express quantitative resistance $\left(\alpha_{R Q}<1\right)$, or not $\left(\alpha_{R Q}=1\right)$. For a cultivar with quantitative resistance, the G2 disease severity index (DI) is decreased by a factor $\alpha_{R Q}\left(\alpha_{R Q}<1\right)$, relative to a susceptible cultivar. Both the disease index $([\mathrm{DI}]=1)$ and the relative yield loss due to infection are calculated as an inverse logit (adapted from Aubertot et al., 2004b):

$$
\mathrm{DI}=\alpha_{R Q} \frac{\mathrm{DI}_{\max } \exp \left(a_{0}+a_{1} N_{\max }+a_{2} T T+a_{3} B M B W\right)}{1+\exp \left(a_{0}+a_{1} N_{\max }+a_{2} T T+a_{3} B M B W\right)}
$$

relative yield loss $=a \mathrm{DI}^{2}+b \mathrm{DI}$

with $\alpha_{R Q}$ is a parameter representing the effect of quantitative resistance $\left(\left[\alpha_{R Q}\right]=1\right), D I_{\max }$ is a parameter representing the maximum value of DI $\left(\mathrm{DI}_{\max }=9\right), N_{\max }$ is the maximum number of leaf spots per plant ( $\left.\left[N_{\max }\right]=1\right)$ during the infection season (from emergence to December 31st), TT: thermal time for the last trimester $\left([\mathrm{TT}]=\theta \mathrm{T}\right.$, with $0{ }^{\circ} \mathrm{C}$ base temperature), and $B M B W$ is the fresh aerial biomass per surface unit at the beginning of winter $\left([B M B W]=\mathrm{M} \mathrm{L}^{-2}\right)$, calculated by the dynamic crop-growth sub-model. $a_{0}, a_{1}, a_{2}, a_{3}$, $a$ and $b$ are parameters $\left(\left[a_{0}\right]=\left[a_{1}\right]=[a]=[b]=1,\left[a_{2}\right]=\theta^{-1},\left[a_{3}\right]=\mathrm{M}^{-1} \mathrm{~L}^{2}\right)$.

The estimation of $\alpha_{R Q}$ (see Appendix 2 in online supplementary file) was based on data collected in an experimental trial in Grignon $\left(48.9^{\circ} \mathrm{N}, 1.9^{\circ} \mathrm{E}, 130 \mathrm{~m}\right.$ elevation, Ile-de-France, $40 \mathrm{~km}$ west from Paris), with 
two cultivars, Aviso (with a quantitative resistance) and Bristol (susceptible). Estimation of other parameters of Eq. (5) and parameters of Eq. (6) is based on data from other French trials (Aubertot et al., 2004b and CETIOM). The yield of each oilseed rape field is calculated according to Eqs. (4), (5), (6). The cumulative number of leaf spots is calculated on a daily basis from the number of spores (see Appendix 3 in online supplementary file), and the maximum number of leaf spots (Eq. (5)) is deduced for over the infection season.

In the infection sub-model, a cross-validation of Eq. (5) (with $\alpha_{Q R}=1$ ) and Eq. (6) was carried out, leading to a RMSEP of 0.96 DI unit for Eq. (5) and RMSEP = 0.08 for Eq. (6) (Aubertot et al., 2004b). The value of $\alpha_{R Q}$ was deemed reasonable (Pinochet, personal communication, see Appendix 2 in online supplementary file). Similarly, the quality of prediction of the number of leaf spots has not been evaluated, but, according to the opinion of experts from INRA and CETIOM, simulated values (in the context of the following example of simulations) were in agreement with field observations.

\section{Evaluation of SIPPOM-WOSR}

Most sub-models have been evaluated independently, and they showed fair to correct predictive quality. The evaluation of the overall model is difficult, given the spatial and temporal scales as well as the number of variables. However, the behaviour of the model was tested by comparing observations and simulations under realistic conditions, in France, in an area known as "région Centre" $\left(46^{\circ} \mathrm{N}, 2^{\circ} \mathrm{E}\right)$, where WOSR is widely cultivated (25-30\% of the cultivated area) and phoma stem canker epidemics have been frequent. An area of 121 fields ( $\operatorname{circa} 16 \mathrm{~km}^{2}$ ) was chosen in the given region. Real field size and shape were used for the calculations in addition to real climatic data. Five types of soils were identified in the studied area and applied proportionally to the 121 fields. The Rlm1 resistant gene was introduced in the 1990s and was tracked in this region between 1994 and 2000 (Rouxel et al., 2003). During this period, crop succession and management were surveyed and this information was used in simulations. The most common crop sequence during this period was WOSR-wheat-barley-wheat. The corresponding proportions of the crops in the simulated area were $25 \%$ of WOSR, $50 \%$ of wheat and $25 \%$ of barley, the three crops being randomly distributed in the simulated area. According to regional surveys, $60 \%$ of WOSR fields were ploughed. The average sowing density was 60 plants $\mathrm{m}^{-2}$, and the most frequent sowing period was the beginning of September. Usually, no fungicide to treat for phoma stem canker was applied. Cultivars with the resistance genes Rlm1 and Rlm4 (no longer efficient during this period, but still present in $25 \%$ of the WOSR cultivars, Huang et al., 2006) were used. The evolution of pathotype frequencies observed by Rouxel et al. (2003) was compared to simulated frequencies. Other variables were observed and compared with simulation, such as the dates of ascospores releases, the number of leaf spots, the G2 severity disease index values or yields, but these results are not presented here. These comparisons between observed data and simulated data under realistic conditions do not in any case allow the evaluation of the predictive quality of the model sensu stricto, as all necessary input variables are not available (e.g., very low initial pathotype frequencies cannot be measured). However, these comparisons are a means to assess SIPPOM's overall behaviour. Additionally, the sensitivity analysis of the model to variation in some non-measurable input variables was assessed (Lô-Pelzer et al., 2010).

Comparisons between simulations and observations showed three main differences (Fig. 2): (i) the observed and simulated frequencies of the double avirulent pathotypes evolved similarly in observation and simulations, but the selection for the double virulent pathotype (a1a4) was delayed in the field in comparison to the simulations, (ii) whereas the double avirulent pathotype (A1A4) disappeared within 4 years in the simulation, while individuals of this pathotype persisted in the field, and (iii) both simple virulent pathotypes (a1A4 and A1a4) were underrepresented in the simulations when compared to the observations from 1994 to 1998, probably due to the faster increase in the double virulent pathotype frequency in simulations. 
Figure 2. Evolution of the frequencies of the pathotypes associated with the resistance genes Rlm1 and Rlm4, following the introduction of the specific resistant gene Rlm1. Comparison between simulated (a) and observed (b) frequencies. A: the pathotype with the considered avirulence gene, a: the pathotype without the considered avirulence gene. Observed frequencies are based on the survey carried out by Rouxel et al. (2003). Around 100 isolates were analyzed each year.

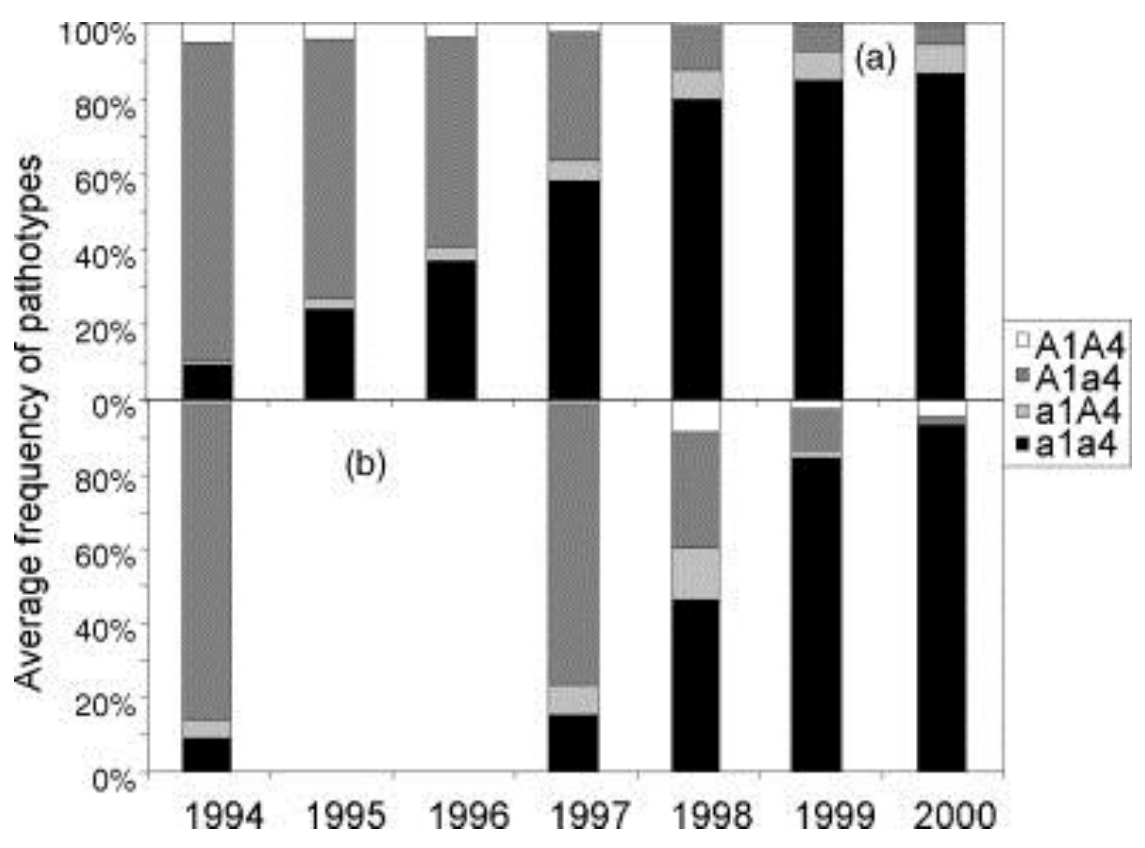

The model properly simulates the evolution of the pathogen population virulent for the major gene Rlm1. However, the multiplication of the virulent pathotypes during the first few years remains to be better simulated, and the current survey of the introduction of the Rlm7 gene in "région Centre" (Pinochet et al., 2007) should contribute to making progress in this direction. The avirulence gene Avrlm4 seems to confer a better fitness on the corresponding pathotypes (Huang et al., 2006). The occurrence of such a cost of virulence could explain why Avrlm4 is maintained in pathogen populations in France, and particularly in the "région Centre" where observations have been carried out. This explains the underrepresentation of the a1A4 as well as the A1A4 pathotypes in simulations. The introduction of a virulence cost in the model could allow simulations to better fit with the observed evolution of pathogen population. Finally, the underrepresentation of the simple virulent pathotype A1a4 in simulations compared to observations might also suggest the occurrence of a cost of virulence associated with the loss of the Avrlm1 gene.

The sensitivity analysis of the model to parameter variations (Lô-Pelzer et al., 2010) is presented in a companion paper.

\section{Examples of output}

Simulations were performed to assess the impact of the spatial distribution of WOSR fields and of crop management on disease severity. Two contrasting crop management plans were defined (Table 1): the first crop management, CM 1, promotes a high yield but allows a limited control of the disease, whereas the second, CM 2, promotes a good control of the disease, mostly through the use of ploughing that reduces the amount of primary inoculum. A $3 \mathrm{~km} \times 3 \mathrm{~km}$ simplified region was defined, with 144 square fields 6.25 ha each. Identical soil conditions were applied to all fields. The crop sequence in all fields was WOSR-wheat-barley. One annual weather dataset was selected from among a previous 20 -year period in Grignon $\left(48.9^{\circ} \mathrm{N}, 1.9^{\circ} \mathrm{E}\right.$, Ile-de-France), and it was repeated over the five years of simulation. Daily wind directions were randomly chosen between $0^{\circ}$ (north) and $90^{\circ}$ (east), and wind intensity was set to constant $\left(5.0 \mathrm{~m} \mathrm{~s}^{-1}\right)$. Annual simulations were carried out, comparing a random distribution of WOSR fields with a caricatured situation where the distance between WOSR fields and fields that are source of ascospores (wheat fields, corresponding to WOSR the year before) was maximised, comparing these spatial situation in the case of both crop managements. 
Table 1. Definition of two contrasting crop managements for winter oilseed rape fields. Practices that have an impact on phoma stem canker are presented in italic.

\begin{tabular}{lll}
\hline Cultural practice & Crop management 1 & Crop management 2 \\
\hline Sowing density & 60 plants $\mathrm{m}^{-2}$ & 30 plants $\mathrm{m}^{-2}$ \\
Sowing date & $1 / 09$ & $15 / 08$ \\
Fungicide & 1 application & No application \\
Other pesticides & 1 herbicide treatment & No other pesticide treatments \\
& 2 insecticide treatments & \\
Organic nitrogen & Orgafor $\left(50 \mathrm{~kg} \mathrm{ha}^{-1}\right)$ & Orgafor $\left(50 \mathrm{~kg} \mathrm{ha}^{-1}\right)$ \\
Mineral nitrogen & 180 units & 180 units \\
Tillage operations & Chisel plough $(20 / 07)$ & Chisel plough $(20 / 07)$ \\
& Rotary harrowing $(1 / 10)$ & $\begin{array}{l}\text { Mouldboard ploughing }(20 / 09) \\
\text { Rotary harrowing }(1 / 10)\end{array}$ \\
& Wheat sowing $(2 / 10)$ & Wheat sowing $(2 / 10)$ \\
\hline
\end{tabular}

The average cumulative number of ascospores per surface unit on WOSR fields was significantly smaller in the situation where distance was maximised between fields that were the source of inoculum and new WOSR fields that were the targets, in comparison to the situation where WOSR fields were randomly distributed $\left(1.4 \times 10^{5}\right.$ spores $\mathrm{m}^{-2}$ and $5 \times 10^{6}$ spores $\mathrm{m}^{-2}$ respectively, for the $\left.\mathrm{CM} 2\right)$. This leads to a significantly lower disease severity (2.3 and 7.3 respectively, Fig. 3). This first set of simulations - no matter how simplistic they are - reveals the fact that the crop mosaic can play a role in the control of disease severity: a crop mosaic with big fields, along with a significant distance between fields which are sources of inoculum and target fields, seems more favourable to decrease phoma severity than a mosaic with relatively small fields distributed throughout the region. SIPPOM will allow the simulation of more complex strategies including both crop mosaic and crop management distribution, i.e., cropping system spatial distribution strategies.

Despite the differences in the number of ascospores lower for the CM 2 in comparison to the CM 1 $\left(5 \times 10^{6}\right.$ spores $\mathrm{m}^{-2}$ and $1.9 \times 10^{7}$ spores $\mathrm{m}^{-2}$ respectively, when WOSR fields are randomly distributed), the disease severity was slightly lower for the crop management 1 . Due to the fact that the sowing date was set to represent early sowing, the crops "experienced" weather condition that were more favourable to infection for the CM 2. This highlights the interactions between crop practices and weather conditions. Moreover, WOSR plants are also less susceptible to disease infection after the 6-leaf stage, but this is not represented in the model, and it also explains why WOSR sown earlier is more sensitive to infection in simulations (contrarily to experimental observations in France or in England; Aubertot et al., 2004a, Gladders and Musa, 1980): crop interception area is higher when spores are released in autumn (due to a higher number of leaves and a higher leaf area) but the receptivity of the crop is not limited. Simulations therefore pointed out possible improvements in the model, in turn requiring further research and experiments to fine tune the comprehension and representation of the relationship between number of ascospores, number of leaf spots, and stem canker severity, in relationship to crop development and growth, under the effect of numerous cultural practices and weather conditions. 
Figure 3. Cumulative number of ascospores (from white to black) on susceptible WOSR fields after one season of dispersal (100 days after emergence of the crop). Fields that are a source of ascospores are wheat fields (with WOSR the previous year), in yellow. WOSR fields are either randomly distributed, or extreme and unrealistic spatial distribution was simulated, where the distance between source (fields with WOSR the previous year) and target fields (planted with WOSR) was maximised. Two crop managements (Table 1) are also compared: crop management 1 promotes a high yield but allows a limited control of the disease, whereas crop management 2 promotes a good control of the disease, mostly with ploughing to reduce the amount of primary inoculum. For both crop managements, a susceptible cultivar is used. (For interpretation of the references to color in this figure legend, the reader is referred to the web version of the article.)

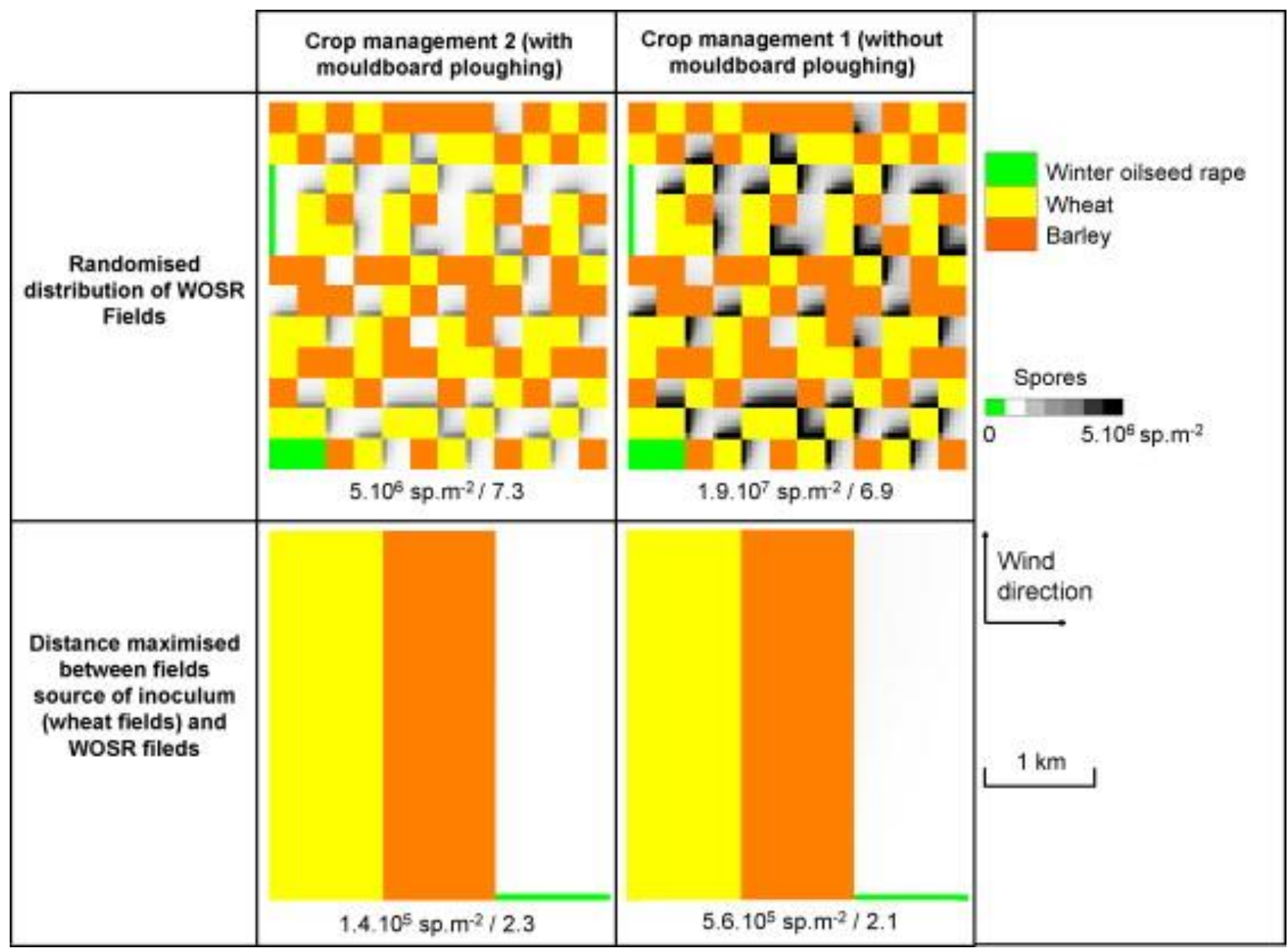

\section{Discussion}

SIPPOM is a spatially explicit model that takes into account different aspects of crop management (genetic, cultural, and chemical control methods), and the spatial distribution of cropping systems. Its aim is to test various disease management strategies that could bring phoma stem canker under control in a durable way by preserving the efficacy of specific resistances (a crucial concern worldwide). It links epidemiological, population, and crop model approaches to simulate L. maculans population dynamics under the influence of various cropping systems. It also takes into account environmental conditions (climate and soil) and their effects on yield and disease severity. The model therefore integrates most of the available knowledge about this disease and the means to bring it under control.

In addition to the qualitative evolution (genetic structure) of pathogen populations, SIPPOM also simulates the size or quantitative evolution of these populations. It is a way to more thoroughly investigate the impacts of weather conditions and control methods (including cultural control methods) as well as how they interact. Indeed, plant pathology models place their focus on cultivar resistance instead of the impacts of cultural practices, even though some of these practices have proven to be efficient in bringing diseases under control when combined with chemical and genetic control methods (this is particularly true for the 
pathosystem under study, Aubertot et al., 2006a, Aubertot et al., 2006b). This principle of combination is the rationale behind Integrated Crop Management concept (Heitefuss, 1989, Ferron and Deguine, 2005), and the impacts of cultural practices are part and parcel of the complexity of pathosystem dynamics that need accounting for. Moreover, the proposed output variables are a way to assess cropping systems according to the economical, ecological, and environmental requirements of Integrated Crop Management (Heitefuss, 1989).

Given the complexity resulting from the integration of genetic, epidemiological and agronomical concept, hypotheses were necessary to simplify the system. For example, in the genetic sub-model, migration, selection, and recombination were chosen to represent the genetic mechanisms and evolutionary forces of the given pathogen. On the contrary, even if mutation, in the case of phoma stem canker, is indeed the cause of the apparition of new virulence, mechanisms of mutation are variable and of several types (e.g., Gout et al., 2006); they are therefore very complex to simulate. Moreover, while in other pathosystems it may take several years to detect new virulent pathotype individuals, virulent $L$. maculans isolates can be found in WOSR fields, as soon as a new resistant gene is introduced in cultivars, due to the variability of mechanisms (Brun et al., 2001). Given this, it was decided not to account for mutation: all pathotypes are assumed to be present in the population at the beginning of a simulation, and the pathotype individuals virulent against an introduced resistance gene are assumed to occur at a very low frequency (less than $10^{-4}$, Lannou and Mundt, 1997).

To simplify the inoculum production sub-model, first of all we decided not to take a generic stance that could have accounted for numerous practices. We opted to restrain SIPPOM to northern European climate and practices. Tillage is the only means to attempt to reduce the quantity of inoculum on surface stubble. Burning is not allowed there and flooding practices do not exist. Moreover, because SIPPOM is being proposed in light of Integrated Crop Management, chemical treatment of stubble is not an option if farmers are to meet the ecological requirements. Finally, emergence mortality due to phoma in Australia or other regions of the world (West et al., 2001) is not taken into account. Second of all, in the current version, the primary inoculum production sub-model simulates inoculum production on stubble from the previous year only. This is consistent with results from Khangura et al. (2007). They have shown that the quantity of inoculum produced on older residues is negligible in comparison to the quantity produced on stubble from the previous year. However, in terms of the qualitative evolution of pathogen populations, inoculum produced on older residues might contribute to the long-term persistence of a virulent pathotype in a region, and this needs investigation.

In the dispersal sub-model, still keeping in mind the need to simplify, dispersal modifications due to landscape topography or vertical elements (such as hedges or trees) were not taken into account. The wind is the only environmental factor assumed to influence the dispersal of spores. Similarly a deterministic version of dispersal (and of the overall model) was opted for instead of a stochastic one. Other approaches can require a stochastic representation of the spore dispersal, as in Peyrard et al. (2007), where the system represented is highly simplified to allow the optimisation of strategies that affect oilseed rape fields spatially connected on a graph. In our case, given the objectives of analysing and ranking control strategies, allowing users to directly simulate the expected value of output variables was deemed sufficient.

Future versions of the model could represent in more detail the complexity of pathosystem dynamics. For example, there is more and more data and knowledge available about mutation, and it could be implemented in the genetic sub-model. Moreover, as discussed in the evaluation section, the fitness cost could be introduced into SIPPOM to better simulate the observation that some avirulent pathotype individuals that are not able to infect new resistant cultivars remain anyway in pathogen populations in a non-negligible proportion. In the inoculum production sub-model, additional practices limiting the quantity of primary inoculum, such as flooding and burning, as well as emergence mortality due to phoma, could be implemented in order to have a more generic version of SIPPOM that would be adaptable to other geographical areas such as Canada and Australia.

\section{Conclusion and perspectives}

By the explicit spatial representation of the epidemiological dynamics of Phytophtora infestans, recent work (Skelsey et al., 2009) has enhanced existing models. However, SIPPOM goes a step further by presenting new characteristics and advantages in terms of the control methods accounted for, the given spatial scale, and the 
predicted outputs. At this stage, SIPPOM has been developed for winter oilseed rape cultivated in northern European weather conditions, but it could be adapted fairly easily to other geographical areas. Besides this, the structure of the model and the development of the code have been designed in order to make it possible to adapt the model to other pathosystems. SIPPOM could therefore be used to investigate various weather conditions, landscape schemes, and pathosystems to help organise strategies at the farm scale or collective strategies at the regional scale that would help bring diseases under control by preserving the efficiency of control methods, including resistant cultivars.

\section{Acknowledgments}

Authors would like to thank E. Hance, M. Morison and E. Mestries (CETIOM) for providing data for the estimation of parameters. They are also grateful to Marie Boillot and Xavier Pinochet for their contribution to the evaluation of the model. This work was carried out with the financial support of the "ANR-Agence Nationale de la Recherche - The French National Research Agency" under the "Programme Agriculture et Développement Durable", project "ANR-05-PADD-05, CEDRE", of the Ministère de l'Agriculture et de la Pêche (CTPS 05-02 Phoma) and of the Agence pour le Développement Agricole et Rural (BioViResDur). This study took place in the UMT Pivert. This work is part of a Ph.D. project co-funded by INRA and CETIOM. The authors are very grateful to Suzette Tanis-Plant for fruitful discussions and editorial advice in English.

\section{Appendix A. Supplementary data}

\section{References}

ADEME et al., 1999 ADEME, AGPB, AGPM, CETIOM, CGB, groupe PLANETE, INRA, ITB, ITCF, Ministère de l'Agriculture, Ministère de l'Industrie, ONIDOL, SOFTDEAL, 1999. Référentiel pour le calcul des bilans énergétiques.

Aubertot et al., 2004a J.N. Aubertot, X. Pinochet, T. Doré The effects of sowing date and nitrogen availability during vegetative stages on Leptosphaeria maculans development on winter oilseed rape Crop Protection, 23 (2004), pp. $635-645$

Aubertot et al., 2004b J.N. Aubertot, X. Pinochet, R. Reau, T. Doré SimCanker: a simulation model for containing phoma stem canker of oilseed rape through cultural practices Proceeding of the 4th International Crop Science Congress, Brisbane, Australia, 27th September-1st October 2004 (2004)

Aubertot et al., 2004c J.N. Aubertot, J.J. Schott, A. Penaud, H. Brun, T. Doré Methods for sampling and assessment in relation to the spatial pattern of phoma stem canker (Leptosphaeria maculans) in oilseed rape European Journal of Plant Pathology, 110 (2004), pp. 183-192

Aubertot et al., 2006a J.N. Aubertot, J.S. West, L. Bousset-Vaslin, M.U. Salam, M.J. Barbetti, A.J. Diggle Improved resistance management for durable disease control: a case study of phoma stem canker of oilseed rape (Brassica napus) European Journal of Plant Pathology, 114 (2006), pp. 91-106

Aubertot et al., 2006b J.N. Aubertot, M.U. Salam, A.J. Diggle, S. Dakowska, M. Jedryczka SimMat, a new dynamic module of blackleg sporacle for the prediction of pseudothecial maturation of L. maculans/L biglobosa species complex. Parameterisation and evaluation under Polish conditions. Integrated control in oilseed crops Bulletin IOBC, 29 (2006), pp. 277-285

Brun et al., 2001 H. Brun, D. Ruer, S. Levivier, I. Somda, A.M. Chèvre, M. Renard Presence in Leptosphaeria maculans populations of isolates virulent on resistance introgressed into Brassica napus from B. nigra B. genome Plant Pathology, 50 (2001), pp. 69-74

Delourme et al., 2006 R. Delourme, A.M. Chèvre, H. Brun, T. Rouxel, M.H. Balesdent, J.S. Dias, P.A. Salisbury, M. Renard, S.R. Rimmer Major gene and polygenic resistance to Leptosphaeria maculans in oilseed rape (Brassica napus) European Journal of Plant Pathology, 114 (2006), pp. 41-52

Diggle et al., 2002 A.J. Diggle, M.U. Salam, G.J. Thomas, H.A. Yang, M. O’Connell, M.W. Sweetingham AnthracnoseTracer: a spatiotemporal model for simulating the spread of anthracnose in a lupin field Phytopathology, 92 (2002), pp. 1110-1121 
Fitt et al., 2006 B.D.L. Fitt, H. Brun, M.J. Barbetti, S.R. Rimmer World-wide importance of phoma stem canker (Leptosphaeria maculans and L. biglobosa) on oilseed rape (Brassica napus) European Journal of Plant Pathology, 114 (2006), pp. 3-15

Ferron and Deguine, 2005 P. Ferron, J.P. Deguine Crop protection, biological control, habitat management and integrated farming. A review Agronomy for Sustainable Development, 25 (2005), pp. 17-24

Flor, 1971 H.H. FlorCurrent status of the gene-for-gene concept Annual Review of Phytopathology, 9 (1971), pp. 275-296

Gabrielle et al., 1998 B. Gabrielle, P. Denoroy, G. Gosse, E. Justes, M.N. Andersen Development and evaluation of a CERES-type model for winter oilseed rape Field Crops Research, 57 (1998), pp. 95-111

Gladders and Musa, 1980 P. Gladders, T.M. Musa Observations on the epidemiology of Leptosphaeria maculans stem canker in winter oilseed rape Plant Pathology, 29 (1980), pp. 28-37

Gout et al., 2006 L. Gout, I. Fudal, M.L. Kuhn, F. Blaise, M. Eckert, L. Cattolico, M.H. Balesdent, T. Rouxel Lost in the middle of nowhere: the AvrLm1 avirulence gene of the Dothideomycete Leptosphaeria maculans Molecular Microbiology, 60 (2006), pp. 67-80

Guo and Fernando, 2005 X.W. Guo, W.G.D. Fernando Seasonal and diurnal patterns of spore dispersal by Leptosphaeria maculans from canola stubble in relation to environmental conditions Plant Disease, 89 (2005), pp. 97-104

Gravesen, 2003 L. Gravesen The Treatment Frequency Index: an indicator for pesticide use and dependency as well as overall load on the environment Pure Conference 2003 (2003), pp. 28-30

Heitefuss, 1989 R. Heitefuss Crop and Plant Protection: The Practical Foundations Ellis Horwood Ltd., Chichester, United Kingdom (1989)

Hovmøller et al., 1997 M.S. Hovmøller, H. Østergård, L. Munk Modelling virulence dynamics of airborne plant pathogens in relation to selection by host resistance in agricultural crop I.R. Crute, J.J. Burdon, E.B. Holub (Eds.), The Gene-for-Gene Relationship in Host-Parasite Interactions, CAB International, Oxon, UK (1997), pp. 173-190

Huang et al., 2006 Y.J. Huang, Z.Q. Li, N. Evans, T. Rouxel, B.D.L. Fitt, M.H. Balesdent Fitness cost associated with loss of the AvrLm4 avirulence function in Leptosphaeria maculans (phoma stem canker of oilseed rape) European Journal of Plant Pathology, 114 (2006), pp. 77-89

IOBC-SROP, 1973 IOBC-SROP, 1973. Statutes. SROP Bulletin, 25 pp.

Jeuffroy and Recous, 1999 M.H. Jeuffroy, S. Recous Azodyn: a simple model simulating the date of nitrogen deficiency for decision support in wheat fertilization European Journal of Agronomy, 10 (1999), pp. 129-144

Jeuffroy et al., 2003 M.H. Jeuffroy, M. Valantin-Morison, L. Saulas, L. Champolivier Azodyn-Rape: a simple model for decision support in rapeseed nitrogen fertilization Proceeding of the 11th International Rapeseed Congress, Copenhagen, Denmark, 6-10th July 2003 (2003)

Khangura et al., 2007 R. Khangura, J. Speijers, M.J. Barbetti, M.U. Salam, A.J. Diggle Epidemiology of blackleg (Leptosphaeria maculans) of canola (Brassica napus) in relation to maturation of pseudothecia and discharge of ascospores in Western Australia Phytopathology, 97 (2007), pp. 1011-1021

Kiyosawa, 1982 S. Kiyosawa Genetics and epidemiological modeling of breakdown of plant disease resistance Annual Review of Phytopathology, 20 (1982), pp. 93-117

Lannou and Mundt, 1997 C. Lannou, C.C. Mundt Evolution of a pathogen population in host mixtures: rate of emergence of complex races Theoretical and Applied Genetic, 94 (1997), pp. 991-999

Leonard, 1993 K.J. Leonard Stability of equilibria in a gene-for-gene coevolution model of host-parasite interactions Phytopathology, 84 (1993), pp. 70-77

Limaux, 1999 Limaux, F., 1999, Modélisation des besoins du blé en azote, de la fourniture du sol et de l'utilisation de l'engrais. Application au raisonnement de la fertilisation en Lorraine. PhD, Institut National Polytechnique de Lorraine, France.

Lô-Pelzer et al., 2009a E. Lô-Pelzer, J.N. Aubertot, O. David, M.H. Jeuffroy, L. Bousset Relationship between the severity of blackleg (Leptosphaeria maculans/L. biglobosa species complex) and subsequent primary inoculum production on oilseed rape stubble Plant Pathology, 58 (2009), pp. 61-70

Lô-Pelzer et al., 2009b E. Lô-Pelzer, J.N. Aubertot, L. Bousset, X. Pinochet, M.H. Jeuffroy Phoma stem canker (Leptosphaeria maculans/L Biglobosa) of oilseed rape (Brassica napus): is the $\mathrm{G}_{2}$ Disease Index a good 
indicator of the distribution of the observed canker severities? European Journal of Plant Pathology, 125 (2009), pp. 515-522

Lô-Pelzer et al., 2010 E. Lô-Pelzer, J.N. Aubertot, L. Bousset, M.U. Salam, M.H. Jeuffroy SIPPOM-WOSR: a Simulator for Integrated Pathogen POpulation Management to manage phoma stem canker on Winter OilSeed Rape. II. Sensitivity analysis Field Crops Research, 118 (2010), pp. 82-93

Makowski et al., 2005 D. Makowski, A. Maltas, M. Morison, R. Reau Calculating N fertilizer doses for oil-seed rape using plant and soil data Agronomy for Sustainable Development, 25 (2005), pp. 159-161

Makowski et al., 2007 D. Makowski, T. Doré, H. Monod A new method to analyse relationships between yield components with boundary lines Agronomy for Sustainable Development, 27 (2007), pp. 119-128

Marcroft et al., 2004 S.J. Marcroft, S.J. Sprague, S.J. Pymer, P.A. Salisbury, B.J. Howlett Crop isolation, not extended rotation length, reduces blackleg (Leptosphaeria maculans) severity of canola (Brassica napus) in south-eastern Australia Australian Journal of Experimental Agriculture, 44 (2004), pp. 601-606

McDonald and Linde, 2002 B.A. McDonald, C. Linde Pathogen population genetics, evolutionary potential, durable resistance Annual Review of Phytopathology, 40 (2002), pp. 349-379

Peyrard et al., 2007 N. Peyrard, R. Sabbadin, E. Lô-Pelzer, J.N. Aubertot A graph-based Markov decision process framework for optimising collective management of diseases in agriculture: application to blackleg on canola Proceeding of the 17th International Congress on Modelling and Simulation (MODSIM'07), Christchurch, New Zealand, December 2007 (2007)

Pinochet et al., 2007 Pinochet, X., Penaud, A., Sauzet, G., Lodé, M., Carpezat, J., Pic, E., Mestries, E., 2007. Introduction of a new specific resistance against Leptosphaeria maculans in oilseed rape commercial varieties in France: Monitoring of introduction and control of virulence behaviour to try to avoid resistance breakdown in a pilot production area in the central part of France. Proceedings of the 12th International Rapeseed Congress. Wuhan, China.

Rouxel et al., 2003 T. Rouxel, A. Penaud, X. Pinochet, H. Brun, L. Gout, R. Delourme, J. Schmit, M.H. Balesdent A 10-year survey of populations of Leptosphaeria maculans in France indicates a rapid adaptation towards the Rlm1 resistance gene of oilseed rape European Journal of Plant Pathology, 109 (2003), pp. 871-881

Salam et al., 2001 M.U. Salam, J. Galloway, R. Khangura, A.J. Diggle, W.J. MacLeod, M.J. Barbetti Spatial spread of blackleg in canola - a regional scale simulation model Proceedings of the 12th Australian Research Assembly on Brassicas, Australia, 2001 (2001)

Salam et al., 2003 M.U. Salam, R.K. Khangura, A.J. Diggle, M.J. Barbetti Blackleg Sporacle: a model for predicting onset of pseudothecia maturity and seasonal ascospore showers in relation to blackleg of canola Phytopathology, 93 (2003), pp. 1073-1081

Salam et al., 2007 M.U. Salam, B.D.L. Fitt, J.N. Aubertot, A.J. Diggle, S. Huang, M.J. Barbetti, P. Gladders, M. Jedryczka, R. Khangura, N. Wratten, W.G.D. Fernando, A. Penaud, X. Pinochet, K. Sivasithamparam Two weather-based models for predicting the onset of seasonal release of ascospores of Leptosphaeria maculans or L. biglobosa Plant Pathology, 56 (2007), pp. 412-423

Schneider, 2005 Schneider, O., 2005. Analyse du mode de gestion des résidus de colza sur l'initiation du cycle de Leptosphaeria maculans (Desm.) Ces et de Not. Ph.D. INA P-G, Paris, France.

Schneider et al., 2006 O. Schneider, J. Roger-Estrade, J.N. Aubertot, T. Doré Effect of seeders and tillage equipment on the vertical distribution of oilseed rape stubble Soil and Tillage Research, 85 (2006), pp. 115-122

Shi-Mai, 1991 Z. Shi-Mai PANCRIN, a prototype model of the pandemic cultivar-race interaction of yellow rust on wheat in China Plant Pathology, 40 (1991), pp. 287-295

Skelsey et al., 2009 P. Skelsey, G.J.T. Kessel, W.A.H. Rossing, W.v.d. Werf Parameterization and evaluation of a spatiotemporal model of the potato late blight pathosystem Phytopathology, 99 (2009), pp. 290-300

Söchting and Verreet, 2004 H.P. Söchting, J.A. Verreet Effects of different cultivation systems (soil management, nitrogen fertilisation) on the epidemics of fungal diseases in oilseed rape (Brassica napus L. var. napus) Zeitschrift für Pflanzenkrankheiten und Pflanzenschutz [Journal of Plant Disease and Protection], 111 (2004), pp. 1-29

Valantin-Morison et al., 2004 Valantin-Morison, M., Jeuffroy, M.H., Champolivier, L., 2004. Evaluation of Azodyn-rape, a simple model for decision support in rapeseed nitrogen. Proceedings of the VIII congress of the European Society of Agronomy, Copenhagen, Denmark., 687-688. 
Van den Bosch and Gilligan, 2003 F. Van den Bosch, C.A. Gilligan Measures of durability of resistance Phytopathology, 93 (2003), pp. 616-625

Wallach et al., 2006 D. Wallach, D. Makowski, J.W. Jones (Eds.), Working with Dynamic Crop Models, Elsevier, Amsterdam (2006)

West et al., 2001 J.S. West, P.D. Kharbanda, M.J. Barbetti, B.D.L. Fitt Epidemiology and management of Leptosphaeria maculans (phoma stem canker) on oilseed rape in Australia, Canada and Europe Plant Pathology, 50 (2001), pp. 10-27 